\title{
Effects of dietary maritime pine (Pinus pinaster)-seed oil on high-density lipoprotein levels and in vitro cholesterol efflux in mice expressing human apolipoprotein A-I
}

\author{
Gaëlle Asset ${ }^{1,3}$, Arnaud Leroy ${ }^{4}$, Eric Bauge ${ }^{1,3}$, Robert L. Wolff ${ }^{5}$, Jean-Charles Fruchart ${ }^{1,3,6}$ \\ and Jean Dallongeville ${ }^{2,3 *}$ \\ ${ }^{1}$ INSERM U-325, ${ }^{2}$ INSERM U-508 and ${ }^{3}$ Département d'Athérosclérose, Institut Pasteur de Lille, \\ 1 rue du Professeur Calmette, 59019 Lille Cedex, France \\ ${ }^{4}$ Laboratoire de Biochimie Appliquée, Université Paris XI, France \\ ${ }^{5}$ Laboratoire de Lipochimie Alimentaire, ISTAB, Université Bordeaux I, France \\ ${ }^{6}$ Université Lille II, 42 rue Paul Duez, 59800, Lille, France
}

(Received 29 July 1999 - Revised 29 November 1999 - Accepted 18 January 2000)

\begin{abstract}
Maritime pine (Pinus pinaster)-seed oil contains two $\Delta 5$ unsaturated polymethylene interrupted fatty acids (all cis-5,9,12-18:3 and all cis-5,11,14-20:3 acids) one of which resembles eicosapentaenoic acid. The goal of the present study was to test whether maritime pine-seed oil consumption affects HDL and apolipoprotein (Apo) A-I levels as well as the ability of serum to promote efflux of cholesterol from cultured cells. To this end, wild type (WT) non-transgenic mice and transgenic mice expressing human ApoA-I (HuA-ITg) were fed on isoenergetic diet containing either $200 \mathrm{~g}$ maritime pine-seed oil $/ \mathrm{kg}$ or $200 \mathrm{~g}$ lard $/ \mathrm{kg}$ for 2 weeks. WT and HuA-ITg mice fed maritime pine-seed oil had lower cholesterol, HDL-cholesterol, LDL-cholesterol and HuA-ITg mice had lower human ApoA-I than those fed lard. The differences in cholesterol $(P<$ 0.0001) and HDL-cholesterol $(P<0.003)$ levels between mice fed on the two diets were more pronounced in the HuA-ITg than in the WT mice. The ability of HuA-ITg serum to promote cholesterol efflux in cultured cells was greater $(P<0.008)$ than that of WT animals. However, the maritime pine-seed oil diet was associated with lower $(P<0.005)$ in vitro cholesterol efflux ability than the lard diet in both mice genotypes. This suggests a negative effect of the maritime pine-seed oil on reverse cholesterol transport. Cholesterol efflux was correlated with serum free or esterified cholesterol and phospholipid levels. The slope of the regression line was smaller in the HuA-ITg than in the WT mice indicating that overexpression of human ApoA-I reduces the negative impact of maritime pine-seed oil on cholesterol efflux. In conclusion, maritime pineseed oil diet lowers HDL-cholesterol and diminishes in vitro cholesterol efflux. This potentially detrimental effect is attenuated by overexpression of human ApoA-I in mice.
\end{abstract}

Maritime pine-seed oil: Apolipoprotein A-I: Lipoproteins: Reverse cholesterol transport

Seeds from conifers such as Pinus koraiensis, Pinus cembra, Pinus cembroides, Pinus edulis, Pinus pinea, Pinus sibirica and Pinus monophylla are currently consumed as condiments for food preparation (Wolff \& Bayard, 1995). Oils extracted from some of these seeds have significant lipidlowering properties in rodents (Ikeda et al. 1992; Sugano et al. 1994). Earlier studies in our laboratory have shown that maritime pine (Pinus pinaster)-seed oil (MPSO) treatment affects lipoprotein metabolism in rats (Asset et al. $1999 \mathrm{~b}$ ) and in transgenic mice lacking apolipoprotein (Apo) E (Asset et al. 1999a) suggesting that MPSO could be an adjuvant to lipid-lowering diets in clinical practice. The most striking effect of a MPSO diet as compared with lard was to lower triacylglycerol in rats and VLDL-cholesterol levels in the ApoE-deficient mice. However, despite these favourable effects, ApoE-deficient mice were not protected against atherosclerosis (Asset et al. 1999a). Among the possible explanations of this finding, an alteration of HDL metabolism could inhibit the expected protective action of MPSO treatment. HDL are dense, protein-rich lipoproteins whose principal function is to transport cholesterol surplus from peripheral tissue to the liver for excretion in the intestinal tract. This is known as reverse cholesterol transport and prevents accumulation of cholesterol in blood 
vessel walls and atherosclerosis formation. Studies in animal models (Hayes \& Khosla, 1992; Wolfe et al. 1993; Ahn et al. 1994) as well as in human subjects (Hegsted et al. 1965, 1993; Keys \& Parlin, 1966; Mata et al. 1992) have shown that substituting dietary saturated by polyunsaturatedenriched oils resulted in a lowering of ApoA-I and HDL levels, indicating a possible deleterious effect of polyunsaturated fats. Therefore, in the process of evaluating the potential interest of a novel oil, it is necessary to assess its impact on HDL levels.

Transgenic animals expressing human Apo have proved to be fruitful models for the investigation of lipoprotein metabolism (Paigen et al. 1994; Breslow, 1996). HuA-ITg mice are characterised by markedly increased levels of HDL (Walsh et al. 1989; Rubin et al. 1991a). These properties confer protection against atherosclerosis to the cholesterolfed (Rubin et al. 1991b) or ApoE-deficient HuA-ITg mice (Plump et al. 1994). Thus, HuA-ITg mice appear to be a useful model to study the impact of nutritional manipulation on HDL metabolism.

The goal of the present study was to assess the effect of MPSO consumption on HDL levels in order to test whether the MPSO, like some other oils enriched in polyunsaturated fatty acids, also decreases HDL-cholesterol. Moreover, since reverse cholesterol transport is an important pathway that confers protection against atherosclerosis, the effect of a MPSO diet on cellular cholesterol efflux was determined in vitro.

\section{Methods}

\section{Animals}

The studies were performed with HuA-ITg mice (Rubin et al. 1991a). These mice were obtained in C57BL/6J background after multiple back-crosses (Transgenic Alliance, IFFA CREDO, L'Arbresle, France). Wild type C57BL/6J (WT) mice were used for control experiments. Before dietary studies all animals were acclimatised for 1 week under conditions of controlled temperature $\left(20 \pm 1^{\circ} \mathrm{C}\right)$ and lighting (dark from 20.00-08.00 hours) in a room of low background noise. The age of the mice was 5 months (SD 1 week).

\section{Dietary experiments}

Before each dietary experiment a blood sample was drawn for randomisation based on cholesterol levels. Mice were housed in cages (2-3 per cage) and were given free access to a fat-free semipurified diet (UAR, Villemoisson sur Orge, France) supplemented with lard (Eurogat, Saint Denis, France) or MPSO (D'ANOSTE, Vendays-Montalivet, France) at $200 \mathrm{~g} / \mathrm{kg}$ for 2 weeks (Table 1). The other major nutrient components were $(\mathrm{g} / \mathrm{kg})$ : carbohydrate 504 , casein 180 , cellulose 48 , mineral mixture 56 , vitamins 8 . Weight gain was monitored throughout these studies. At the end of each dietary experiment, mice were food-deprived for $4 \mathrm{~h}$ and exsanguinated under diethyl ether anaesthesia by cardiac puncture. Experiment 1 was a three experimental factors design with ten mice per cell to compare the effect of MPSO and lard on lipid and lipoprotein variables in male and female WT and HuA-ITg mice. Experiment 2 was
Table 1. Fatty acid composition $(\mathrm{g} / 100 \mathrm{~g})$ of the lipid sources

\begin{tabular}{lcc}
\hline Fatty acids & Lard & Maritime pine-seed oil \\
\hline Saturated & & \\
$16: 0$ & 24 & $3 \cdot 6$ \\
$17: 0$ & $0 \cdot 1$ & $0 \cdot 1$ \\
18:0 & $15 \cdot 5$ & $2 \cdot 4$ \\
Monounsaturated & & \\
16:1 & $2 \cdot 6$ & $0 \cdot 2$ \\
18:1 & $43 \cdot 2$ & $18 \cdot 1$ \\
$11-20: 1$ & $0 \cdot 7$ & $1 \cdot 0$ \\
Polyunsaturated & & \\
$9,12-18: 2$ & $11 \cdot 6$ & $55 \cdot 9$ \\
$9,12,15-18: 3$ & $0 \cdot 8$ & $1 \cdot 3$ \\
$11,14-20: 2$ & nd & $0 \cdot 8$ \\
5 olefinic & & \\
$5,9-18: 2$ & nd & 0.7 \\
$5,9,12-18: 3$ & nd & $7 \cdot 1$ \\
$5,11-20: 2$ & nd & $0 \cdot 8$ \\
$5,11,14-20: 3$ & nd & $7 \cdot 1$ \\
Others & $1 \cdot 5$ & 0.9 \\
\hline
\end{tabular}

nd, not detected.

a three experimental factors design with three mice per cell to compare the effect of MPSO and lard on cellular cholesterol efflux in male and female WT and HuA-ITg mice.

\section{Lipid measurements}

Blood was collected on EDTA or dry tubes for plasma (experiment 1) or serum (experiment 2) preparation respectively. Plasma and serum were separated by centrifugation $(630 \mathrm{~g})$ for $20 \mathrm{~min}$ at $4^{\circ} \mathrm{C}$. Lipids were determined enzymatically using commercially available kits for cholesterol (Cholesterol C System; Boehringer Mannheim, Mannheim, Germany), triacylglycerol (Triglycerides GPO-PAP; Boehringer Mannheim) and phospholipids (Phospholipids PAP 150; BioMérieux, Lyon, France).

\section{Gel-filtration chromatography}

Gel-filtration chromatography was performed using a Superose 6 HR 10/30 column (Pharmacia, Pharmacia LKB Biotechnology, S-751 82 Uppsala, Sweden). The gel was allowed to equilibrate with PBS $(10 \mathrm{mM})$ containing $0 \cdot 1 \mathrm{~g}$ EDTA/l and $0 \cdot 1 \mathrm{~g}$ sodium azide/l; $150 \mu \mathrm{l}$ plasma were eluted with the buffer at room temperature at a flow rate of $0.02 \mathrm{ml} / \mathrm{min}$. Elution profiles were monitored at $280 \mathrm{~nm}$ and recorded with an analog-recorder chart tracing system (Pharmacia, Pharmacia LKB Biotechnology). The effluents were collected in $0.24 \mathrm{ml}$ fractions. Cholesterol and phospholipids were measured in each collected fraction using commercially available enzymatic kits (Cholesterol C System, Boehringer Mannheim; Phospholipids PAP 150, BioMérieux).

\section{Agarose-gel electrophoresis}

Agarose-gel electrophoresis was performed according to Noble (Noble, 1968) with a Beckman Paragon system 
(Beckman Instruments France SA, Gagny, France). Briefly, plasma $(5 \mu \mathrm{l})$ was applied on a $0.5 \%$ agarose gel (Paragon LIPO lipoprotein electrophoresis, Beckman Instruments France SA). Electrophoresis was performed for $30 \mathrm{~min}$ in a barbital buffer $(\mathrm{pH} 8.6)$ at $100 \mathrm{~V}$. Gels were stained with Sudan Black B.

\section{High-density lipoprotein isolation and measurements}

The fraction of serum $1.063<\mathrm{d}<1.21 \mathrm{~g} / \mathrm{ml}$ was separated by sequential ultracentrifugation using a Beckman TLA100.4 rotor (Beckman Instruments France SA) at $480000 \mathrm{~g}$ and $10^{\circ} \mathrm{C}$. Serum aliquots $(100 \mu \mathrm{l})$ were adjusted to a density of $1.063 \mathrm{~g} / \mathrm{ml}$ with potassium bromide and spun for $3 \mathrm{~h}$. The supernatant fraction was discarded. Then, the infranatant fraction was adjusted to a density of $1.21 \mathrm{~g} / \mathrm{ml}$ and spun twice for $3 \mathrm{~h}$. The resulting serum fraction $1.063<$ $\mathrm{d}<1.21 \mathrm{~g} / \mathrm{ml}$ was dialysed against a $10 \mathrm{mM}$-phosphate buffer containing $0 \cdot 1 \mathrm{~g}$ EDTA/l and $0 \cdot 1 \mathrm{~g}$ sodium azide/l. Lipids and proteins were determined enzymatically using commercially available kits for cholesterol (Cholesterol C System, Boehringer Mannheim), triacylglycerol (Triglycerides GPO-PAP; Boehringer Mannheim), phospholipids (Phospholipids PAP 150; BioMérieux) and proteins (BCA protein assay reagent; Pierce, Rockford, IL, USA).

\section{$\left[{ }^{3} H\right]$ cholesterol efflux}

$\left[{ }^{3} \mathrm{H}\right]$ cholesterol fractional efflux was carried out essentially as previously described (de la Llera Moya et al. 1994). Briefly, the efflux potential of mice serum was assayed by incubating individual fresh unfrozen samples at $37^{\circ} \mathrm{C}$ with the $\left[{ }^{3} \mathrm{H}\right] \mathrm{cho}-$ lesterol-labelled Fu5AH cells and then quantifying the amount of radio-labelled cellular cholesterol released to the acceptor-containing medium. Acceptors were extensively dialysed against Eagle's minimal essential medium. Serum specimens were used at a concentration of $5 \%$ and cells were exposed to the acceptor serum for $4 \mathrm{~h}$. At least three wells of cells were incubated with each sample. Samples were diluted into Eagle's minimal essential medium just before addition to cells. The labelled cell cholesterol released was measured in a portion of the medium by using standard liquid scintillation counting. The efflux phase was ended by removing the serum-containing medium from each well. This efflux medium was collected into tubes that had been chilled in an ice-bath and centrifuged at $4^{\circ} \mathrm{C}$ for $5 \mathrm{~min}$ at $1000 \mathrm{~g}$ to remove any floating cells. The cell-free medium was maintained at $0^{\circ} \mathrm{C}$ until frozen at $-70^{\circ} \mathrm{C}$ for storage and further analysis. At the end of the efflux period, cell monolayers were washed with PBS. The lipids were extracted by overnight incubation at room temperature with isopropanol, and cellular lipid radioactivity was measured in a portion of the extract. Fractional efflux was calculated as the amount of the label released to the medium divided by the total label in each well. To standardise the cellular response obtained with different batches of cells and labelling medium, a human serum standard prepared from a pool was always included as a test serum. Although Fu5AH cells are rat hepatoma-derived cells this model has been validated and is widely used to assess serum-mediated cholesterol efflux. The limits and advantages of this cellular model are extensively discussed in a previous paper (de la Llera Moya et al. 1994).

\section{Statistical analysis}

Three-way ANOVA was used to compare diet, sex and genotype effects. Whenever ANOVA was statistically significant $(P<0.05)$, the Scheffé test was used for post hoc analysis. The SPSS Software release 7.5 for Windows was used (SPSS Institute Inc., Paris, France).

\section{Results \\ Experiment 1}

Lipid and lipoprotein. Three-way ANOVA showed no significant interaction among any combination of factors and sex, i.e. $\operatorname{sex} \times$ diet $\times$ genotype or $\operatorname{sex} \times$ diet or $\operatorname{sex} \times$ genotype, suggesting that male and female mice had a similar response to diet. There was, in contrast, a statistically significant interaction between genotype and diet for cholesterol $(P<0 \cdot 0001)$, phospholipids $(P<0 \cdot 0001)$ and HDL-cholesterol $(P<0.003)$ indicating that HuA-ITg and WT mice had a different response to diet (Table 2). Cholesterol, phospholipids or HDL-cholesterol levels were lower in both WT and HuA-ITg mice supplemented with MPSO than lard. Therefore, the interaction between genotype and diet was quantitative rather than qualitative. That is, the lipid and lipoprotein differences between the MPSO and the lard group were greater in HuA-ITg than WT mice. Finally, there was a statistically significant main effect of diet for LDL-cholesterol $(P<0.01)$ and triacylglycerol $(P<0 \cdot 05)$. MPSO-supplemented mice had lower levels of LDL-cholesterol and triacylglycerol than their respective lard-fed controls. The analyses of the electrophoretic properties of lipoproteins on agarose gel showed no major difference between diets.

High-density lipoprotein size. The cholesterol chromatography elution profile of WT mice indicated that the lowering of HDL upon MPSO treatment was similar across the HDL size range (Fig. 1). In HuA-ITg mice the decrease in HDL-cholesterol (Fig. 1) was more pronounced in the large HDL fractions than in the smaller fractions. Therefore, not only the levels but also the size distribution of HDL were affected in HuA-ITg mice with a shift toward smaller particles in the MPSO-treated animals. Similar results were obtained with measurement of phospholipids (data not shown).

Human apolipoprotein A-I in HuA-ITg mice. Two-way ANOVA indicated a statistically significant interaction $(P<$ 0.05) between sex and diet for human ApoA-I (Fig. 2). Human ApoA-I levels $(P<0.0001)$ were lower in both male and female mice treated with MPSO than lard. The difference between dietary groups was more pronounced in males than in females suggesting a quantitative rather than a qualitative interaction.

\section{Experiment 2}

High-density lipoprotein composition. The lipid composition analysis of HDL revealed no major difference 
Table 2. Plasma lipids (mmol/l) of wild type and HuA-ITg mice fed on lard or maritime pine-seed-oil diet $(200 \mathrm{~g} / \mathrm{kg}) \dagger$ (Mean values and standard deviations for ten male and ten female mice per group)

\begin{tabular}{|c|c|c|c|c|c|c|c|c|c|c|}
\hline & \multicolumn{4}{|c|}{ Wild type } & \multicolumn{4}{|c|}{ HuA-ITg } & & \\
\hline & \multicolumn{2}{|c|}{ Lard } & \multicolumn{2}{|c|}{$\begin{array}{c}\text { Maritime } \\
\text { pine-seed oil }\end{array}$} & \multicolumn{2}{|c|}{ Lard } & \multicolumn{2}{|c|}{$\begin{array}{c}\text { Maritime } \\
\text { pine-seed oil }\end{array}$} & \multicolumn{2}{|l|}{ ANOVA: $P \ddagger$} \\
\hline & Mean & SD & Mean & SD & Mean & SD & Mean & SD & Genotype $\times$ diet interaction & Diet main effect \\
\hline \multicolumn{11}{|l|}{ Cholesterol } \\
\hline Female & 2.28 & 0.32 & $1.65^{\star}$ & $0 \cdot 10$ & 5.93 & 0.34 & $4 \cdot 00^{\star \star \star}$ & 0.42 & 0.0001 & 0.0001 \\
\hline $\begin{array}{l}\text { Male } \\
\end{array}$ & $3 \cdot 31$ & 0.54 & $2 \cdot 40^{* * *}$ & 0.29 & 7.09 & 0.88 & $4 \cdot 83^{\star \star \star}$ & 0.52 & & \\
\hline Female & 1.52 & 0.23 & 1.00 & 0.11 & 4.28 & 0.62 & $3 \cdot 29^{\star *}$ & 0.35 & 0.003 & 0.0001 \\
\hline Male & 2.54 & 0.33 & 2.01 & 0.27 & 5.94 & 0.75 & $4.06^{\star \star *}$ & 0.51 & & \\
\hline \multicolumn{11}{|l|}{ LDL-CHO§ } \\
\hline Female & 0.51 & 0.11 & 0.37 & 0.08 & 0.96 & 0.69 & 0.50 & 0.09 & NS & 0.008 \\
\hline Male & 0.45 & $0 \cdot 13$ & 0.24 & 0.04 & 0.51 & 0.08 & 0.40 & 0.12 & & \\
\hline \multicolumn{11}{|c|}{ Triacylglycerol } \\
\hline Female & 0.38 & 0.11 & 0.33 & $0 \cdot 13$ & 0.40 & 0.09 & 0.40 & 0.08 & NS & 0.028 \\
\hline Male & 0.56 & $0 \cdot 10$ & $0.34^{* *}$ & $0 \cdot 12$ & 0.44 & 0.07 & 0.41 & 0.04 & & \\
\hline \multicolumn{11}{|c|}{ Phospholipids } \\
\hline Female & 1.90 & $0 \cdot 15$ & 1.47 & $0 \cdot 15$ & $5 \cdot 07$ & 0.44 & $3.85^{\star \star *}$ & 0.37 & 0.0001 & 0.0001 \\
\hline Male & $3 \cdot 27$ & 0.37 & $2 \cdot 50^{\star *}$ & 0.24 & $7 \cdot 21$ & 0.59 & $5 \cdot 29^{\star \star \star}$ & 0.39 & & \\
\hline
\end{tabular}

$\mathrm{HDL}-\mathrm{CHO}$, high-density lipoprotein cholesterol; LDL-CHO, low-density lipoprotein cholesterol.

Mean values were significantly different from those of the lard-fed group: ${ }^{\star} P<0.05$, ${ }^{\star \star} P<0.01$, ${ }^{\star \star \star} P<0.001$ (post hoc analysis of maritime pine-seed oil $v$. lard). †For details of diets and procedures see pp. 254-255 and Table 1.

$\ddagger$ Three-way ANOVA was used to compare means, followed by Scheffé for post hoc analysis. Interaction and main effects terms are those of the ANOVA.

$\S \mathrm{HDL}-\mathrm{CHO}$ and LDL-CHO were determined by gel-filtration chromatography.

(a)

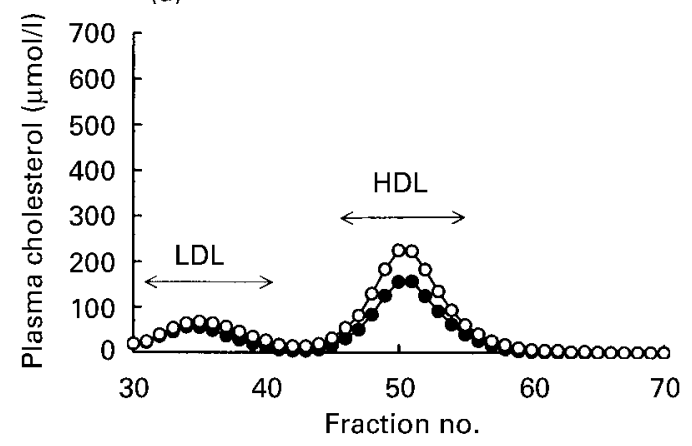

(b)

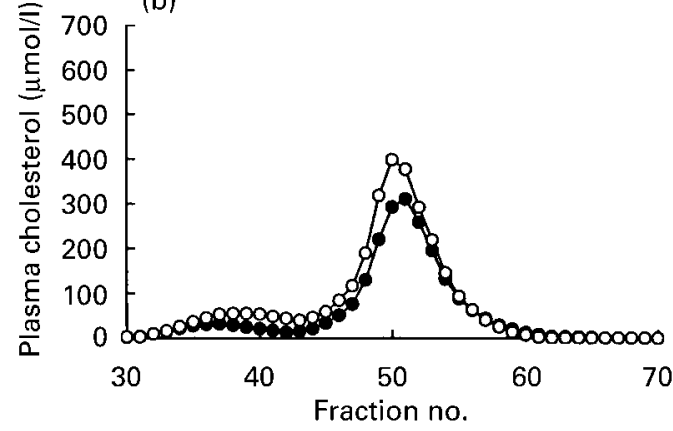

(c)

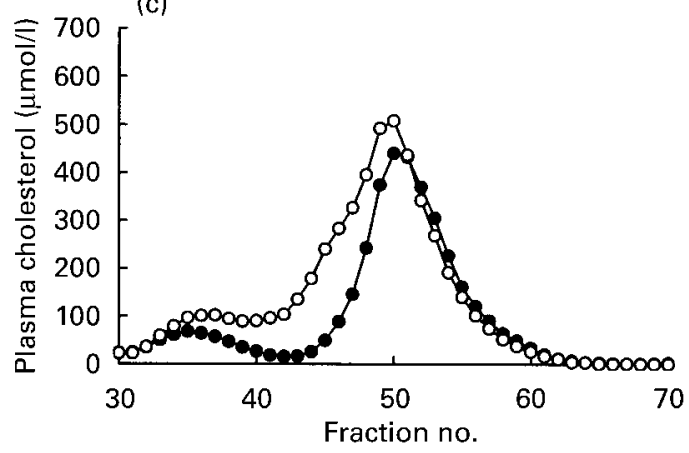

(d)

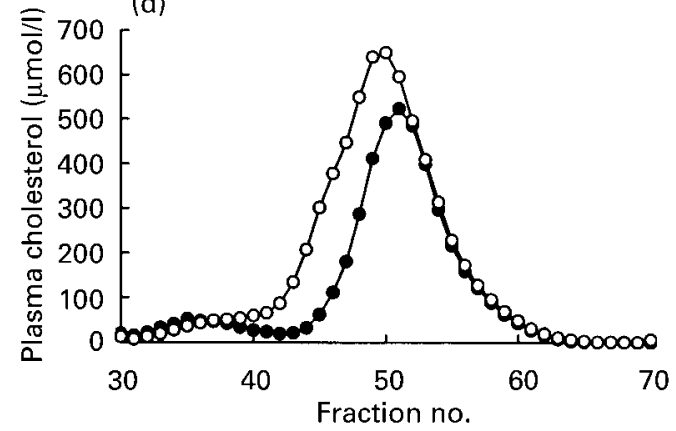

Fig. 1. Cholesterol gel-filtration chromatography profile of the LDL and HDL plasma fraction in (a, b), wild type and (c, d), HuA-ITg mice fed on (•), maritime pine-seed oil or $(O)$, lard diet $(200 \mathrm{~g} / \mathrm{kg}$ diet). Pooled plasma of ten females $(\mathrm{a}, \mathrm{c})$ and ten males $(\mathrm{b}$, d). For details of diets and procedures see pp. 254-255 and Table 1. 


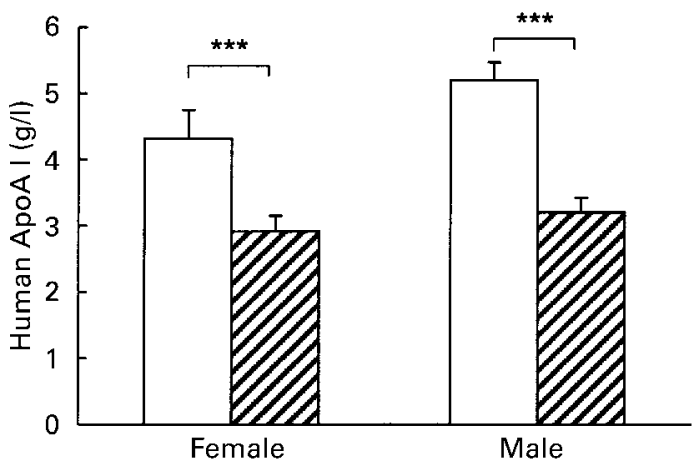

Fig. 2. Human apolipoprotein (Apo)A-I levels in HuA-ITg mice fed on 四, maritime pine-seed oil or $\square$, lard diet $(200 \mathrm{~g} / \mathrm{kg}$ diet). For details of diets and procedures see pp. 254-255 and Table 1. Values are mean for ten female and ten male mice per diet group with standard deviations represented by vertical bars. There was a statistically significant interaction of sex $\times$ diet: $P<0.05$ (two-way ANOVA). Mean values were significantly different: ${ }^{* \star \star} P<0.001$ (post hoc analyses with the test of Scheffé).

between diets. In WT mice, cholesterol, phospholipids and protein contents were $19 \%, 28 \%$ and $53 \%$ in lard-fed mice and $18 \%, 29 \%$ and $52 \%$ in MPSO-fed mice. In HuA-ITg the values were $17 \%, 33 \%$ and $50 \%$ and $16 \%, 31 \%$ and $53 \%$ in the lard and MPSO group respectively. Triacylglycerol was not detected.

In vitro cholesterol efflux. Three-way ANOVA showed no significant interaction among any combination of factors and sex or genotype i.e. sex $\times$ diet $\times$ genotype or sex $\times$ diet or gender $\times$ genotype or genotype $\times$ diet. There was a statistically significant main effect of diet for serum freecholesterol $(P<0.0001)$, cholesterol esters $(P<0.002)$ and phospholipids $(P<0.002)$. These variables were lower in the MPSO-fed mice than in the lard-fed mice for both WT and HuA-ITg mice (Table 3).

In respect of in vitro cholesterol efflux, there was no evidence for a statistically significant interaction among any combination of the three factors. There was, however, a

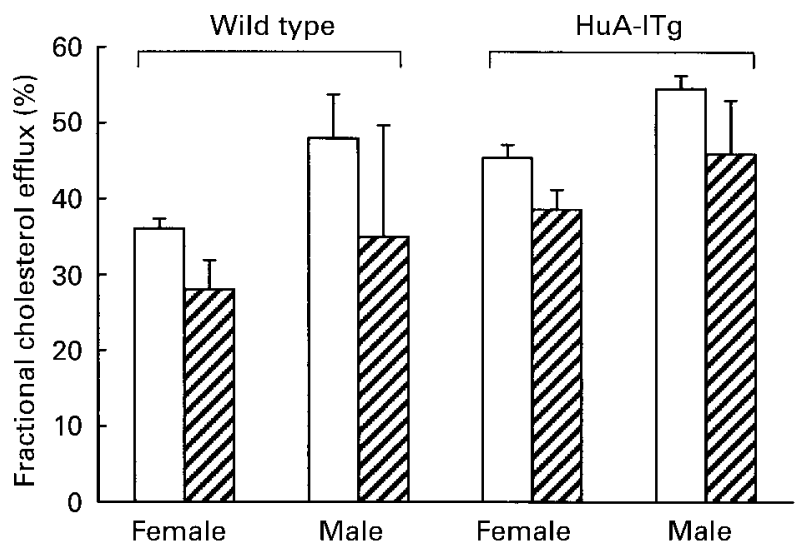

Fig. 3. Fractional cholesterol efflux in wild type and HuA-ITg mice on 四, maritime pine-seed oil or $\square$, lard diet ( $200 \mathrm{~g} / \mathrm{kg}$ diet). For details of diets and procedures see pp. 254-255 and Table 1. Values are means for three female or three male mice per diet group with standard deviations represented by vertical bars. There was a main effect of diet: $P<0.01$ (three-way ANOVA).

statistically significant main effect of sex $(P<0.008)$, genotype $(P<0.008)$ and diet $(P<0.05)$ on cholesterol efflux (Fig. 3). In vitro cholesterol efflux was lower in females than in males, in WT than in HuA-ITg mice, and in the MPSO group than in the lard group. The ability of serum to promote in vitro cholesterol efflux was correlated to serum phospholipids and to serum free or esterified cholesterol levels (Fig. 4). The slopes of the regression lines were different between mouse genotypes. For a given difference in serum phospholipids, free or esterified cholesterol level between mice, in vitro cholesterol efflux difference was smaller in the HuA-ITg mice than in the WT group.

\section{Discussion}

Maritime pine seeds are harvested in France on a multitonne-scale for reforestation. The oil extracted from the

Table 3. Free, esterified cholesterol and phospholipids ( $\mathrm{mmol} / \mathrm{l})$ of wild type and HuA-ITg mice fed on lard or maritime pine-seed-oil diet $(200 \mathrm{~g} / \mathrm{kg}) \dagger$ (Mean values and standard deviations for three male and three female mice per group)

\begin{tabular}{|c|c|c|c|c|c|c|c|c|c|c|}
\hline & \multicolumn{4}{|c|}{ Wild type } & \multicolumn{4}{|c|}{ HuA-ITg } & & \\
\hline & \multicolumn{2}{|c|}{ Lard } & \multicolumn{2}{|c|}{$\begin{array}{c}\text { Maritime } \\
\text { pine-seed oil }\end{array}$} & \multicolumn{2}{|c|}{ Lard } & \multicolumn{2}{|c|}{$\begin{array}{c}\text { Maritime } \\
\text { pine-seed oil }\end{array}$} & \multicolumn{2}{|l|}{ ANOVA: $P \ddagger$} \\
\hline & Mean & SD & Mean & SD & Mean & SD & Mean & SD & Genotype $\times$ diet interaction & Diet main effect \\
\hline \multicolumn{11}{|c|}{ Free cholesterol } \\
\hline Female & 0.45 & 0.09 & 0.25 & 0.08 & 1.36 & 0.28 & 0.68 & 0.13 & NS & 0.0001 \\
\hline Male & 0.60 & 0.08 & 0.38 & $0 \cdot 14$ & 1.82 & 0.40 & 0.92 & 0.40 & & \\
\hline \multicolumn{11}{|c|}{ Cholesterol esters } \\
\hline Female & $2 \cdot 28$ & 0.13 & 1.54 & 0.13 & $4 \cdot 31$ & 1.25 & 2.53 & 0.58 & NS & 0.002 \\
\hline Male & $2 \cdot 83$ & $0 \cdot 11$ & 1.54 & 0.98 & $5 \cdot 04$ & 0.81 & 3.49 & 1.43 & & \\
\hline \multicolumn{11}{|c|}{ Phospholipids } \\
\hline Female & $2 \cdot 19$ & $0 \cdot 16$ & 1.68 & $0 \cdot 12$ & 4.50 & 0.59 & 3.06 & 0.41 & NS & 0.002 \\
\hline Male & $3 \cdot 12$ & 0.26 & $2 \cdot 11$ & 1.06 & $6 \cdot 79$ & $0 \cdot 78$ & $4 \cdot 38$ & 1.65 & & \\
\hline
\end{tabular}

Mean values were significantly different from those of the lard-fed group: ${ }^{\star} P<0.05,{ }^{\star \star} P<0.01,{ }^{\star \star \star} P<0.001$ (post hoc analysis of maritime pine-seed oil $v$. lard; no significant differences were detected).

†For details of diets and procedures see pp. 254-255 and Table 1.

$¥$ Three-way ANOVA was used to compare means, followed by Scheffé for post hoc analysis. Interaction and main effects terms are those of the ANOVA 

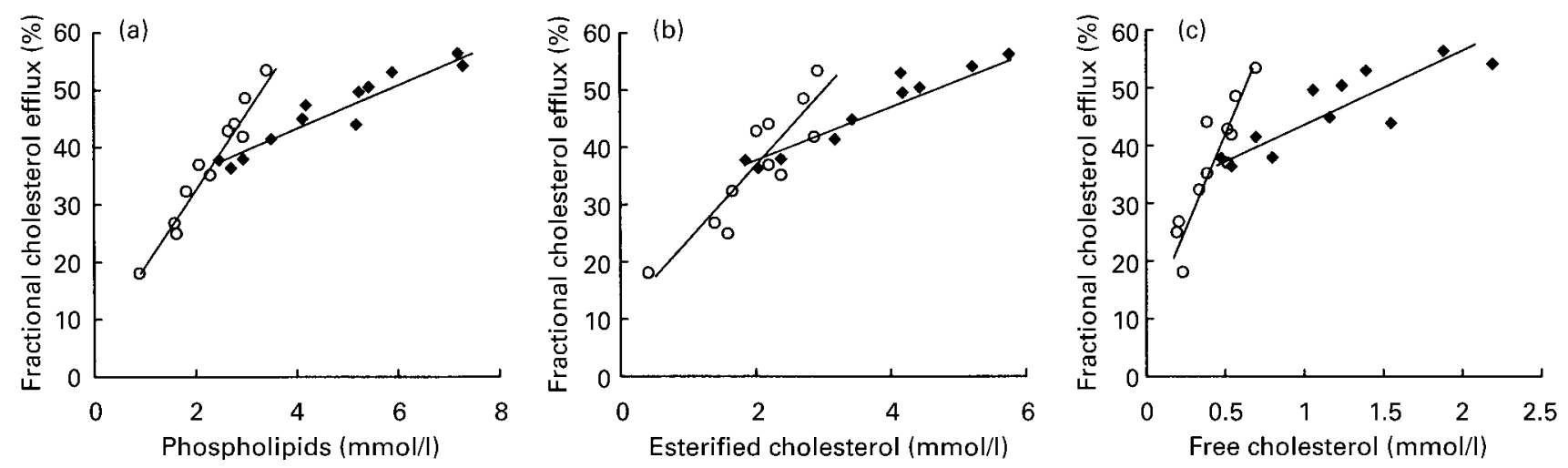

Fig. 4. Regression line between fractional cholesterol efflux and serum (a), phospholipids, (b), esterified cholesterol and (c), free cholesterol. Each line represents the regression of either wild type (O) or HuA-ITg ( ) mice fed on both maritime pine-seed oil or lard (200 g/kg diet). For details of diets and procedures see pp. 254-255 and Table 1. Values are means from three female and three male mice per diet group. Fractional cholesterol efflux v.: phospholipids, WT $r 0.95$, HuA-ITg $r$ 0.98; esterified cholesterol, WT $r$ 0.98, HuA-ITg $r$ 0.87; free cholesterol, WT r 0.91, HuA-ITg $r 0.85$.

seeds of this pine contains an average of $16 \mathrm{~g} \Delta 5$ unsaturated polymethylene interrupted fatty acids $/ 100 \mathrm{~g}$ fat, namely of all cis-5,9,12-18:3 and all cis-5,11,14-20:3 acids that differ in fatty acid composition from previously described pineseed oils (Wolff \& Bayard, 1995). MPSO decreases plasma triacylglycerol and VLDL-cholesterol levels in rats (Asset et al. 1999b) indicating a potential interest in lipid-lowering therapy. The goal of the present study was to assess the impact of MPSO supplementation on HDL levels and cellular cholesterol efflux. To this end, WT and HuA-ITg mice were given a diet containing $200 \mathrm{~g}$ lard or maritime pine oil $/ \mathrm{kg}$ for 2 weeks. The results indicated that MPSO diet lowers HDLcholesterol levels and reduces the ability of mice serum to promote in vitro cholesterol efflux as compared with lard. The latter effect was attenuated by overexpression of human ApoA-I. These data suggest that the decrease in HDL levels that is observed upon MPSO treatment might be less harmful in mice with elevated levels of ApoA-I.

HDL-cholesterol levels were lower in WT and HuA-ITg mice supplemented with MPSO than with lard suggesting an unfavourable effect of MPSO treatment on HDL metabolism. The mechanism by which MPSO lowers HDL is not known. Previous studies in rodents had shown that a polyunsaturated fatty acid-enriched diet was associated with low levels of HDL-cholesterol as compared with a more saturated-fat diet (Leach \& Holub, 1984). The reduction in HDL-cholesterol was attributed to either decreased production (Shepherd et al. 1978; Sorci-Thomas et al. 1989; Stucchi et al. 1991) or increased catabolic rates of ApoA-I (Brousseau et al. 1995b) depending on the experimental model, the type of diet and the metabolic variables that were measured (Stucchi et al. 1991). In these studies, hepatic ApoA-I mRNA levels were either low (Sorci-Thomas et al. 1989; Kushwaha et al. 1991; Stucchi et al. 1991) or not affected (Sorci-Thomas et al. 1992; Ahn et al. 1994; Brousseau et al. 1995a,b) so that no clear mechanism of HDL-lowering has emerged from these investigations. The MPSO diet clearly resulted in lower HDL levels in WT mice and lower HDL and ApoA-I levels in HuA-ITg mice indicating an effect independent of genotype. This result is different from the effect of fibrate, a lipid-lowering agent, which decreases HDL-cholesterol levels in WT mice but increases HDL-cholesterol and human ApoA-I in HuA-ITg mice as well as in human subjects (Berthou et al. 1996). Thus, if these observations can be extended to human physiology, these findings would predict a detrimental effect of MPSO diet on HDL-cholesterol and ApoA-I levels in human subjects.

An important function of HDL is to transport cholesterol from peripheral tissues to the liver where the cholesterol is excreted in the intestinal tract. The first step of reverse cholesterol transport involves efflux of cholesterol from peripheral cells to HDL. This transport is essential for cholesterol homeostasis in peripheral tissues and for protection against atherosclerosis. The ability of mice serum to promote in vitro cholesterol efflux was higher in HuA-ITg mice than in WT animals in agreement with an earlier investigation (Castro et al. 1997). However, in vitro cholesterol efflux was lower in both HuA-ITg and WT mice treated with MPSO than with lard indicating an effect independent of genotype. This finding is in agreement with previous observations which had shown a tendency (although not statistically significant) towards lower levels of in vitro cholesterol efflux in primates fed polyunsaturated-enriched oils instead of more saturated fats (Sola et al. 1993) suggesting a common effect of polyunsaturated fatty acid-enriched diets (Gillotte et al. 1998). The mechanism by which MPSO diminishes in vitro cholesterol efflux as compared with lard has not been investigated. However, the decrease in serum HDL levels certainly contributes to this effect. In rodents, HDL particles represent the vast majority of circulating lipoproteins. As in human subjects, HDL facilitate the movement of cholesterol from cultured cells to incubation media. Therefore, the lowering of HDL levels that is associated with MPSO diet as compared with lard certainly reduces the ability of serum to promote cholesterol efflux in vitro. On the other hand, changes in HDL lipids fatty-acid length and degree of unsaturation affect the physico-chemical properties of HDL which in turn affect the ability of HDL to promote cellular cholesterol efflux (Wassall et al. 1992). Overall, feeding MPSO results in decreased HDL and ApoA-I levels as well as in reduced cholesterol efflux indicating a potentially harmful effect of 
MPSO on the first step of reverse cholesterol transport. This finding could explain the lack of protective effect of MPSO diet against atherosclerosis in ApoE-deficient mice (Asset et al. 1999a).

The ability of mice serum to promote in vitro cholesterol efflux was correlated with its concentration in free or esterified cholesterol and phospholipids. However, the relationship between serum lipids and in vitro cholesterol efflux was different in HuA-ITg and WT mice. The slope of the regression line was less marked in the HuA-ITg than in the WT mice. Thus, for a given decrease in serum free or esterified cholesterol or phospholipids levels between MPSO- and lard-fed mice the corresponding reduction in cholesterol efflux was less pronounced in HuA-ITg mice than in WT animal. This indicates that overexpression of ApoA-I interferes with cholesterol efflux in MPSO-fed mice and attenuates the detrimental effect of feeding a MPSO diet on cholesterol efflux in vitro. In a tentative extrapolation of these results to human physiology, MPSO treatment could be used in patients with elevated triacylglycerol and HDLcholesterol levels. In this type of patient, the benefit of reducing triacylglycerol would not be hampered by a major impact on reverse cholesterol transport.

In conclusion, the results of the present study demonstrate that MPSO supplementation is associated with lower levels of HDL in HuA-ITg and WT mice as compared with lard. In human subjects, the dietary substitution of saturated fatty acids by polyunsaturated fatty acids results in decreased levels of HDL and ApoA-I. This has led to recommendation of moderate consumption of polyunsaturated fatty acids in lipid-lowering diets. The results of the present study indicate that MPSO, like other polyunsaturated fatty acid-rich oils, also decreases ApoA-I and HDL levels, indicating a potentially undesirable effect of this oil on HDL metabolism. These data suggest that a careful analysis of the impact of MPSO on HDL metabolism is necessary in human subjects before recommending its use as dietary complement to lipid disorder treatments.

\section{Acknowledgements}

The authors were supported in part by the Institut Pasteur de Lille and the Ministère Français de l'Enseignement Supérieur et de la Recherche. This study work was funded by unrestricted grants from Fondation de France, Aide à la Recherche en Lipidologie (Laboratoires Fournier), the Fondation Pour la Recherche Médicale and from l'Institut Appert, as well as by a grant 'Aliment 2000' no. 96 G 0182 (Ministère de l'Enseignement Supérieur et de la Recherche). Authors would like to thank Society BERTIN and D'ANOSTE for kindly providing maritime pine-seed oil for the study.

\section{References}

Ahn YS, Smith D, Osada J, Li Z, Schaefer EJ \& Ordovas JM (1994) Dietary fat saturation affects apolipoprotein gene expression and high density lipoprotein size distribution in golden Syrian hamsters. Journal of Nutrition 124, 2147-2155.

Asset G, Bauge E, Wolff RL, Fruchart JC \& Dallongeville J (1999a) Pinus pinaster oil affects lipoprotein metabolism in apolipoprotein E-deficient mice. Journal of Nutrition 129, 1972-1978.

Asset G, Staels B, Wolff RL, Bauge E, Madj Z, Fruchart JC \& Dallongeville J (1999b) Effects of Pinus pinaster and Pinus koraiensis seed oil supplementation on lipoprotein metabolism in the rat. Lipids 34, 39-44.

Berthou L, Duverger N, Emmanuel F, Langouet S, Auwerx J, Guillouzo A, Fruchart JC, Rubin E, Denefle P, Staels B \& Branellec D (1996) Opposite regulation of human versus mouse apolipoprotein A-I by fibrates in human apolipoprotein A-I transgenic mice. Journal of Clinical Investigation 97, 24082416.

Breslow JL (1996) Mouse models of atherosclerosis. Science 272, 685-688.

Brousseau ME, Ordovas JM, Osada J, Fasulo J, Robins SJ, Nicolosi RJ \& Schaefer EJ (1995a) Dietary monounsaturated and polyunsaturated fatty acids are comparable in their effects on hepatic apolipoprotein mRNA abundance and liver lipid concentrations when substituted for saturated fatty acids in cynomolgus monkeys. Journal of Nutrition 125, 425-436.

Brousseau ME, Schaefer EJ, Stucchi AF, Osada J, Vespa DB, Ordovas JM \& Nicolosi RJ (1995b) Diets enriched in unsaturated fatty acids enhance apolipoprotein A-I catabolism but do not affect either its production or hepatic mRNA abundance in cynomolgus monkeys. Atherosclerosis 115, 107-119.

Castro G, Nihoul LP, Dengremont C, de Geitere C, Delfly B, Tailleux A, Fievet C, Duverger N, Denefle P, Fruchart JC \& Rubin EM (1997) Cholesterol efflux, lecithin-cholesterol acyltransferase activity, and pre-beta particle formation by serum from human apolipoprotein A-I and apolipoprotein A-I/apolipoprotein A-II transgenic mice consistent with the latter being less effective for reverse cholesterol transport. Biochemistry 36, 2243-2249.

de la Llera Moya M, Atger V, Paul JL, Fournier N, Moatti N, Giral P, Friday KE \& Rothblat G (1994) A cell culture system for screening human serum for ability to promote cellular cholesterol efflux. Relations between serum components and efflux, esterification, and transfer. Arteriosclerosis and Thrombosis 14, $1056-1065$.

Gillotte KL, Lund-Katz S, de la Llera Moya M, Parks JS, Rudel LL Rothblat GH \& Phillips MC (1998) Dietary modification of high density lipoprotein phospholipid and influence on cellular cholesterol efflux. Journal of Lipid Research 39, 2065-2075.

Hayes KC \& Khosla P (1992) Dietary fatty acid thresholds and cholesterolemia. FASEB Journal 6, 2600-2607.

Hegsted DM, Ausman LM, Johnson JA \& Dallal GE (1993) Dietary fat and serum lipids: an evaluation of the experimental data. American Journal of Clinical Nutrition 57, 875-883.

Hegsted DM, McGandy RB, Myers ML \& Stare FJ (1965) Quantitative effects of dietary fat on serum cholesterol in man. American Journal of Clinical Nutrition 17, 281-295.

Ikeda I, Oka T, Koba K, Sugano M \& Lie KJM (1992) 5c,11c,14ceicosatrienoic acid and $5 \mathrm{c}, 11 \mathrm{c}, 14 \mathrm{c}, 17 \mathrm{c}$-eicosatetraenoic acid of Biota orientalis seed oil affect lipid metabolism in the rat. Lipids 27, 500-504.

Keys A \& Parlin RW (1966) Serum cholesterol response to changes in dietary lipids. American Journal of Clinical Nutrition 19, 175-181.

Kushwaha RS, McMahan CA, Mott GE, Carey KD, Reardon CA, Getz GS \& McGill HCJ (1991) Influence of dietary lipids on hepatic mRNA levels of proteins regulating plasma lipoproteins in baboons with high and low levels of large high density lipoproteins. Journal of Lipid Research 32, 1929-1940.

Leach AB \& Holub BJ (1984) The effect of dietary lipid on the lipoprotein status of the Mongolian gerbil. Lipids 19, 25-33.

Mata P, Garrido JA, Ordovas JM, Blazquez E, Alvarez-Sala LA, Rubio MJ, Alonso R \& de Oya M (1992) Effect of dietary 
monounsaturated fatty acids on plasma lipoproteins and apolipoproteins in women. American Journal of Clinical Nutrition 56, 77-83.

Noble RP (1968) Electrophoretic separation of plasma lipoproteins in agarose gel. Journal of Lipid Research 9, 693-700.

Paigen B, Plump AS \& Rubin EM (1994) The mouse as a model for human cardiovascular disease and hyperlipidemia. Current Opinion in Lipidology 5, 258-264.

Plump AS, Scott CJ \& Breslow JL (1994) Human apolipoprotein A-I gene expression increases high density lipoprotein and suppresses atherosclerosis in the apolipoprotein E-deficient mouse. Proceedings of the National Academy of Sciences of the United States of America 91, 9607-9611.

Rubin EM, Ishida BY, Clift SM \& Krauss RM (1991a) Expression of human apolipoprotein A-I in transgenic mice results in reduced plasma levels of murine apolipoprotein A-I and the appearance of two new high density lipoprotein size subclasses. Proceedings of the National Academy of Sciences of the United States of America 88, 434-438.

Rubin EM, Krauss RM, Spangler EA, Verstuyft JG \& Clift SM (1991b) Inhibition of early atherogenesis in transgenic mice by human apolipoprotein AI. Nature 353, 265-267.

Shepherd J, Packard CJ, Patsch JR, Gotto AMJ \& Taunton OD (1978) Effects of dietary polyunsaturated and saturated fat on the properties of high density lipoproteins and the metabolism of apolipoprotein A-I. Journal of Clinical Investigation 61, 15821592.

Sola R, Motta C, Maille M, Bargallo MT, Boisnier C, Richard JL \& Jacotot B (1993) Dietary monounsaturated fatty acids enhance cholesterol efflux from human fibroblasts. Relation to fluidity, phospholipid fatty acid composition, overall composition, and size of HDL3. Arteriosclerosis and Thrombosis 13, 958-966.

Sorci-Thomas M, Hendricks CL \& Kearns MW (1992) HepG2 cell LDL receptor activity and the accumulation of apolipoprotein $B$ and $\mathrm{E}$ in response to docosahexaenoic acid and cholesterol. Journal of Lipid Research 33, 1147-1156.

Sorci-Thomas M, Prack MM, Dashti N, Johnson F, Rudel LL \& Williams DL (1989) Differential effects of dietary fat on the tissue-specific expression of the apolipoprotein A-I gene: relationship to plasma concentration of high density lipoproteins. Journal of Lipid Research 30, 1397-1403.

Stucchi AF, Hennessy LK, Vespa DB, Weiner EJ, Osada J, Ordovas JM, Schaefer EJ \& Nicolosi RJ (1991) Effect of corn and coconut oil-containing diets with and without cholesterol on high density lipoprotein apoprotein A-I metabolism and hepatic apoprotein A-I mRNA levels in cebus monkeys. Arteriosclerosis and Thrombosis 11, 1719-1729.

Sugano M, Ikeda I, Wakamatsu K \& Oka T (1994) Influence of Korean pine (Pinus koraiensis)-seed oil containing cis-5, cis-9,cis-12-octadecatrienoic acid on polyunsaturated fatty acid metabolism, eicosanoid production and blood pressure of rats. British Journal of Nutrition 72, 775-783.

Walsh A, Ito Y \& Breslow JL (1989) High levels of human apolipoprotein A-I in transgenic mice result in increased plasma levels of small high density lipoprotein (HDL) particles comparable to human HDL3. Journal of Biological Chemistry 264, 6488-6494.

Wassall SR, McCabe RC, Ehringer WD \& Stillwell W (1992) Effects of dietary fish oil on plasma high density lipoprotein. Electron spin resonance and fluorescence polarization studies of lipid ordering and dynamics. Journal of Biological Chemistry 267, 8168-8174.

Wolfe MS, Parks JS, Morgan TM \& Rudel LL (1993) Childhood consumption of dietary polyunsaturated fat lowers risk for coronary artery atherosclerosis in African green monkeys. Arteriosclerosis and Thrombosis 13, 863-875.

Wolff RL \& Bayard CC (1995) Fatty acid composition of some pine seed oils. Journal of the American Oil Chemists' Society 72 , 1043-1046. 